\title{
Pengembangan Buku Petunjuk Praktikum Fisika: Pengujian Jenis KAWAT KONDUKTOR KOMERSIAL
}

\author{
Sumarli ${ }^{1)}$, Eka Murdani ${ }^{2)}$, Andika Kusuma Wijaya ${ }^{3)}$ \\ 1) Program Studi Pendidikan Fisika STKIP Singkawang \\ E-mail: sumarliphysics@gmail.com \\ 2) Program Studi Pendidikan Fisika STKIP Singkawang \\ E-mail: ekamurdani@gmail.com \\ 3) Program Studi Pendidikan Fisika STKIP Singkawang \\ E-mail: andikakusumawijaya 1988@gmail.com
}

\begin{abstract}
Abstrak. Penelitian ini bertujuan untuk menghasilkan buku petunjuk praktikum fisika pengujian jenis kawat konduktor komersial serta mengetahui kelayakan dan respon mahasiswa terhadap buku petunjuk praktikum fisika pengujian jenis kawat konduktor komersial. Rancangan penelitian yang digunakan adalah penelitian pengembangan atau $R \& D$ (Research and Development) yang dimodifikasi dari Sugiyono. Penelitian dilaksanakan di Laboratorium Fisika STKIP Singkawang dengan mahasiswa program studi Pendidikan Fisika dan dosen pengampu mata kuliah listrik magnet sebagai subyek penelitian. Hasil penelitian menunjukkan buku petunjuk praktikum fisika pengujian jenis kawat konduktor komersial yang dihasilkan memiliki kriteria "Sangat Layak" berdasarkan penilaian dari ahli materi dengan persentase mencapai 90,00\%, penilaian dari ahli media dengan persentase mencapai 95,00\%, dan penilaian akhir dosen pengampu mata kuliah listrik magnet dengan persentase mencapai $86,76 \%$. Buku petunjuk praktikum fisika mendapat respon "Sangat baik" dari mahasiswa dengan persentase mencapai $76 \%$ pada uji coba terbatas I dan mencapai $80 \%$ pada uji coba terbatas II.
\end{abstract}

Kata Kunci: Petunjuk Praktikum Fisika, Kawat Konduktor Komersial

\section{PEndahuluan}

Sekolah Tinggi Keguruan dan Ilmu Pendidikan (STKIP) Singkawang sebagai salah satu Lembaga Pendidikan Tinggi dan Kependidikan (LPTK) senantiasa berupaya menghasilkan calon guru yang cerdas, kompetitif, beretika dan memiliki jiwa sosial entrepreneurship. STKIP Singkawang menerapkan berbagai metode pembelajaran yang dapat meningkatkan pemahaman dan prestasi belajar mahasiswa seperti perkuliahan berbasis multimedia. Secara khusus pada program studi Pendidikan Fisika diselenggarakan pula proses pembelajaran baik melalui pemodelan, animasi, simulasi maupun praktikum langsung di laboratorium [1] [2].

Berdasarkan visi dan misi program studi Pendidikan Fisika STKIP Singkawang terutama pada misi yang berbunyi "Mengembangkan laboratorium Program Studi Pendidikan Fisika sehingga dapat menunjang kegiatan eksperimen dan penelitian pendidikan, mengembangkan berbagai multimedia serta model pembelajaran fisika", maka peneliti tertarik untuk membantu mewujudkan misi tersebut.Peneliti memiliki ide untuk membuat suatu inovasi pembelajaran yaitu mengembangkan kegiatan eksperimen di laboratorium fisika STKIP Singkawang dengan merancang buku petunjuk praktikum fisika yang pada akhirnya bisa diterapkan di laboratorium fisika. Hal ini sesuai dengan tujuan program studi Pendidikan Fisika yakni membentuk kepribadian sarjana pendidikan fisika yang kreatif, inovatif dan adaptif sesuai dengan perkembangan ilmu pengetahuan dan teknologi.

Fisika sebagai suatu subjek yang terlihat abstrak, sulit untuk dipelajari dan konsep-konsep fisika biasanya dipelajari hanya mengandalkan kemampuan mengingat mahasiswa terhadap ilmu fisika yang telah disampaikan oleh dosen mereka [3]. Banyak penelitian menunjukkan bahwa pembelajaran fisika berbasis praktikum berperan penting dalam memperdalam pengetahuan dan pemahaman mahasiswa terhadap konsep-konsep fisika [3]. Penelitian ini memilih buku petunjuk praktikum sebagai variasi pedoman praktikum dengan bahasa yang mudah diterima mahasiswa sehingga mahasiswa mampu belajar mandiri tanpa dibimbing secara langsung oleh dosen [4]. 
Berdasarkan hasil observasi kebutuhan yang dilakukan peneliti melalui wawancara dengan salah satu dosen pengampu mata kuliah diketahui bahwa buku petunjuk praktikum fisika pada mata kuliah listrik magnet masih belum tersedia khususnya pada materi pengujian jenis kawat konduktor. Pengembangan buku petunjuk praktikum ini dianggap perlu karena mampu membangun pengetahuan dan pengalaman langsung mahasiswa dalam pembelajaran praktikum tanpa dibimbing secara langsung oleh dosen. Oleh karena itu, buku petunjuk praktikum yang akan dirancang dalam penelitian ini adalah pengujian jenis kawat konduktor komersial yang sering ditemukan di pasaran.

Untuk mengetahui kebenaran suatu jenis kawat konduktor yang telah didapatkan di pasaran, maka perlu diuji melalui proses praktikum di laboratorium fisika. Kawat konduktor adalah kawat yang dapat menghantarkan arus listrik dengan baik. Kawat konduktor yang baik adalah kawat yang memiliki nilai konduktivitas listriknya besar tetapi nilai resistivitasnya kecil [5]. Konduktivitas adalah kemampuan suatu bahan untuk menghantarkan arus listrik sedangkan resistivitas adalah kemampuan suatu bahan untuk menghambat arus listrik. Resistansi suatu kawat mempunyai kebergantungan nilai terhadap suhu. Dengan mengetahui resistivitas suatu kawat dan kebergantungan hambatan kawat terhadap suhu, maka jenis kawat tersebut dapat ditentukan [5].

Secara umum, penelitian ini bertujuan untuk mengembangkan buku petunjuk praktikum fisika pada pengujian jenis kawat konduktor komersial. Secara khusus, penelitian ini bertujuan untuk menghasilkan buku petunjuk praktikum fisika pada pengujian jenis kawat konduktor komersial, mengetahui kelayakan dan respon mahasiswa terhadap buku petunjuk praktikum fisika pada pengujian jenis kawat konduktor komersial.

\section{METODE}

Rancangan penelitian yang digunakan adalah penelitian pengembangan atau $R \& D$ (Research and Development) yang dimodifikasi dari Sugiyono [6]. Prosedur penelitian pengembangan yaitu orientasi masalah, pengumpulan data, desain produk, validasi produk, revisi produk, uji coba terbatas I, revisi produk, validasi produk, revisi produk, uji coba terbatas II, revisi produk, dan produk final. Penelitian dilaksanakan di Laboratorium Fisika STKIP Singkawang dengan mahasiswa program studi Pendidikan Fisika dan dosen pengampu mata kuliah listrik magnet sebagai subyek penelitian.

Variabel yang diukur dalam penelitian ini adalah kelayakan buku petunjuk praktikum fisika dan respon mahasiswa terhadap buku petunjuk praktikum fisika pengujian jenis kawat konduktor komersial. Kelayakan buku petunjuk praktikum fisika diukur berdasarkan hasil penilaian dari ahli materi dan ahli media, serta dosen pengampu mata kuliah listrik magnet melalui instrumen berupa angket. Respon mahasiswa diukur berdasarkan hasil angket respon mahasiswa terhadap buku petunjuk praktikum fisika. Angket yang digunakan merupakan modifikasi dari angket yang disusun oleh Crisnandari [7] dengan jawaban pernyataan pada angket menggunakan skala Likert. Data dianalisis secara deskriptif persentase.

\section{HASIL DAN PEMBAHASAN}

\section{A. Produk Buku Petunjuk Praktikum Fisika}

Pada penelitian ini telah dikembangkan buku petunjuk praktikum fisika yang mencakup materi pengujian jenis kawat konduktor komersial. Buku petunjuk praktikum fisika dibuat dalam ukuran kertas A4 (21 cm x 29,7 cm). Buku ini juga memiliki gambar yang mendukung materi praktikum sehingga membantu memudahkan mahasiswa dalam melaksanakan petunjuk praktikum sesuai prosedur. Buku petunjuk praktikum hasil pengembangan memiliki beberapa komponen sebagai berikut: (1) satu halaman sampul depan yang memuat judul praktikum, nama penulis, asal program studi, logo instansi dan alamat instansi serta dilengkapi gambar-gambar kawat konduktor sebagai penghias sampul depan; (2) satu halaman kata pengantar yang memuat kata pengantar dari penulis; (3) tiga halaman tata tertib praktikum fisika yang memuat peraturan-peraturan yang harus dipatuhi oleh praktikan selama praktikum; (4) satu halaman daftar isi memuat daftar halaman agar mempermudah dalam mencari halaman pokok materi; (5) delapan halaman teori ketidakpastian pengukuran memuat teori-teori ketidakpastian pengukuran; (6) empat halaman praktikum 1 memuat praktikum dengan judul pengujian jenis kawat berdasarkan resistivitas kawat; (7) empat halaman praktikum 2 memuat praktikum dengan judul pengujian jenis kawat berdasarkan koefisien suhu kawat; (8) satu halaman sistematika penulisan laporan praktikum memuat langkahlangkah penulisan laporan akhir praktikum; (9) satu halaman daftar pustaka memuat sumber materi/pustaka.

Buku petunjuk praktikum fisika pengujian jenis kawat konduktor komersial memiliki halaman praktikum terdiri dari bagian-bagian sebagai berikut: (1) judul praktikum; (2) tujuan percobaan berisi tujuan yang akan dicapai pada praktikum; (3) tinjauan pustaka berisi materi yang terkait dengan praktikum tersebut; (4) alat dan bahan berisi alat dan bahan yang digunakan ketika melakukan praktikum; (5) langkah-langkah praktikum berisi petunjuk atau cara-cara saat melakukan praktikum; (6) tabel pengamatan adalah tabel yang digunakan untuk menuliskan hasil pengamatan; (7) tugas pendahuluan adalah tugas yang harus dikerjakan oleh praktikan dan diserahkan sebelum melakukan praktikum; (8) tugas akhir adalah tugas yang harus dikerjakan praktikan setelah praktikum sebelum meninggalkan laboratorium dan dimuat dalam laporan praktikum.

Produk berupa buku petunjuk praktikum fisika pengujian jenis kawat konduktor komersial telah melalui tahap penilaian kelayakan oleh ahli materi, ahli media, dan dosen pengampu mata kuliah listrik magnet. Hasil penilaian I yang disertai saran dan masukan dari para pakar menjadi dasar dalam revisi buku petunjuk praktikum fisika kemudian diujicobakan dalam uji coba terbatas I. Hasil uji coba terbatas I kemudian direvisi kembali dan dilakukan penilaian II oleh para pakar. Hasil penilaian II yang disertai saran dan masukan dari para pakar menjadi dasar dalam revisi kembali buku petunjuk praktikum fisika yang nantinya akan diujicobakan dalam uji 
coba terbatas II. Hasil revisi dari hasil uji coba terbatas II adalah produk akhir berupa buku petunjuk praktikum fisika pengujian jenis kawat konduktor komersial yang siap digunakan sebagai pedoman praktikum mahasiswa program studi Pendidikan Fisika STKIP Singkawang di laboratorium fisika, khususnya pada mata kuliah listrik magnet.

\section{B. Penilaian Kelayakan Buku Petunjuk Praktikum Fisika}

Penilaian kelayakan buku petunjuk praktikum fisika pengujian jenis kawat konduktor komersial dilakukan guna memeroleh penilaian dari para pakar dalam pengembangan buku petunjuk praktikum ini. Selain itu, tujuan dari penilaian kelayakan buku petunjuk praktikum fisika adalah untuk memeroleh masukan yang membangun agar buku petunjuk praktikum fisika yang dikembangkan menjadi lebih baik. Berikut sajian penilaian oleh para pakar.

\section{Penilaian Ahli Materi}

Kriteria persentase skor penilaian buku petunjuk praktikum fisika pengujian jenis kawat konduktor komersial oleh ahli materi dilakukan berdasarkan Badan Standar Nasional Pendidikan (BSNP) yang ditampilkan pada Tabel 1. Rekapitulasi hasil penilaian ahli materi terhadap buku petunjuk praktikum fisika pengujian jenis kawat konduktor komersial ditampilkan pada Tabel 2.

TABEL 1

Kriteria PERSENTASe SKor PENILAIAN BERDASARKAN BSNP

\begin{tabular}{cc}
\hline Interval \% skor & Kriteria \\
\hline $81,25 \%<$ skor $\leq 100 \%$ & Sangat Layak \\
$62,50 \%<$ skor $\leq 81,25 \%$ & Layak \\
$43,75 \%<$ skor $\leq 62,50 \%$ & Kurang Layak \\
$25 \%<$ skor $\leq 43,75 \%$ & Tidak Layak \\
\hline
\end{tabular}

TABEL 2

REKAPITULASI HASIL PENILAIAN AHLI MATERI

\begin{tabular}{clcc}
\hline No & \multicolumn{1}{c}{ Aspek Penilaian } & Persentase & Kategori \\
\hline 1 & Cakupan materi & $93,75 \%$ & Sangat Layak \\
2 & Akurasi materi & $91,67 \%$ & Sangat Layak \\
3 & Kemutakhiran materi & $87,50 \%$ & Sangat Layak \\
4 & Memacu keingintahuan & $93,75 \%$ & Sangat Layak \\
5 & Penyajian & $81,25 \%$ & Layak \\
6 & Keterlaksanaan & $90,63 \%$ & Sangat Layak \\
& praktikum & & \\
\hline & Rata-Rata Persentase & $90,00 \%$ & Sangat Layak \\
\hline
\end{tabular}

Hasil penilaian ahli materi menunjukkan bahwa rata-rata persentase sebesar 90,00\%. Dengan demikian buku petunjuk praktikum fisika termasuk kategori "Sangat Layak" menurut ahli materi.

\section{Penilaian Ahli Media}

Kriteria persentase skor penilaian buku petunjuk praktikum fisika pengujian jenis kawat konduktor komersial oleh ahli media dilakukan berdasarkan Tabel 2. Rekapitulasi hasil penilaian ahli media terhadap buku petunjuk praktikum fisika pengujian jenis kawat konduktor komersial ditampilkan pada Tabel 3 .

TABEL 3

ReKapitulasi Hasil PEnilaian Ahli Media

\begin{tabular}{|c|c|c|c|}
\hline No & Aspek Penilaian & Persentase & Kriteria \\
\hline 1 & Tampilan umum & $91,67 \%$ & $\begin{array}{l}\text { Sangat } \\
\text { Layak }\end{array}$ \\
\hline 2 & Penyajian & $93,75 \%$ & $\begin{array}{l}\text { Sangat } \\
\text { Layak }\end{array}$ \\
\hline 3 & Bahasa/keterbacaan & $100,00 \%$ & $\begin{array}{l}\text { Sangat } \\
\text { Layak }\end{array}$ \\
\hline & Rata-Rata Persentase & $95,00 \%$ & $\begin{array}{l}\text { Sangat } \\
\text { Layak }\end{array}$ \\
\hline
\end{tabular}

Hasil penilaian ahli media menunjukkan bahwa rata-rata persentase sebesar 95,00\%. Dengan demikian buku petunjuk praktikum fisika termasuk kategori "Sangat Layak" menurut ahli media.

\section{Penilaian Dosen Pengampu}

Kriteria persentase skor penilaian buku petunjuk praktikum fisika pengujian jenis kawat konduktor komersial oleh dosen pengampu mata kuliah listrik magnet dilakukan berdasarkan Tabel 2. Rekapitulasi hasil penilaian dosen pengampu terhadap buku petunjuk praktikum fisika pengujian jenis kawat konduktor komersial ditampilkan pada Tabel 4.

TABEL 4

ReKapitulasi Hasil Penilaian Dosen PENGampu

\begin{tabular}{clcc}
\hline No & Aspek Penilaian & Persentase & Kriteria \\
\hline 1 & Cakupan materi & $87,50 \%$ & Sangat Layak \\
2 & Akurasi materi & $100,00 \%$ & Sangat Layak \\
3 & Memacu keingintahuan & $87,50 \%$ & Sangat Layak \\
4 & Penyajian & $75,00 \%$ & Layak \\
5 & Tampilan umum & $87,50 \%$ & Sangat Layak \\
6 & Bahasa/keterbacaan & $81,25 \%$ & Layak \\
7 & Keterlaksanaan & $93,75 \%$ & Sangat Layak \\
& praktikum & $86,76 \%$ & Sangat Layak \\
\hline & Rata-Rata Persentase & &
\end{tabular}

Hasil penilaian dosen pengampu menunjukkan bahwa ratarata persentase sebesar $86,76 \%$. Dengan demikian buku petunjuk praktikum fisika termasuk kategori "Sangat Layak" menurut dosen pengampu.

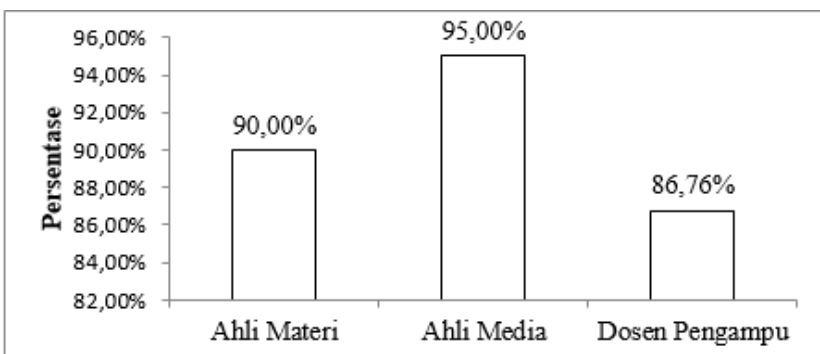

Gambar 1. Diagram Hasil Penilaian Ahli Materi, Ahli Media, dan Dosen Pengampu 


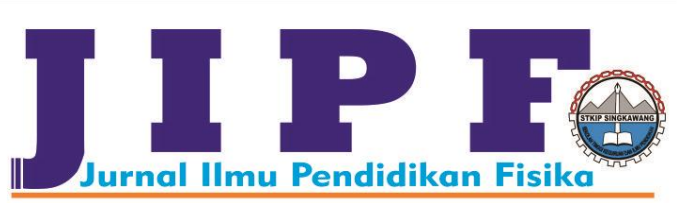

Kelayakan buku petunjuk praktikum fisika pengujian jenis kawat konduktor komersial berdasarkan penilaian ahli materi, ahli media, dan dosen pengampu ditampilkan oleh diagram batang pada Gambar 1 .

Berdasarkan Gambar 1, kelayakan buku petunjuk praktikum fisika pengujian jenis kawat konduktor komersial menurut ahli materi memiliki kategori sangat layak dengan persentase 90,00\%; menurut ahli media memiliki kategori sangat layak dengan persentase 95,00\%; sedangkan menurut dosen pengampu mata kuliah listrik magnet memiliki kategori sangat layak dengan persentase $86,76 \%$.

\section{Respon Mahasiswa Terhadap Buku Petunjuk Praktikum Fisika}

Untuk mengetahui respon mahasiswa terhadap buku petunjuk praktikum fisika pengujian jenis kawat konduktor komersial yang telah dikembangkan, maka dilakukan uji coba terbatas I dan II. Uji coba terbatas I dilakukan kepada enam orang mahasiswa program studi Pendidikan Fisika STKIP Singkawang yang terdiri dari tiga orang mahasiswa semester IV dan tiga orang mahasiswa semester VI. Sedangkan uji coba terbatas II dilakukan kepada semua mahasiswa program studi Pendidikan Fisika STKIP Singkawang baik semester II, IV, maupun VI yang berjumlah 30 orang. Respon mahasiswa terhadap buku petunjuk praktikum fisika pengujian jenis kawat konduktor komersial dikategorikan "Sangat Baik" jika $(75 \%<$ skor $\leq 100 \%)$; "Baik" jika $(50 \%<$ skor $\leq 75 \%)$; "Kurang Baik" jika $(25 \%<$ skor $\leq 50 \%)$; dan "Tidak Baik" jika skor $\leq 25 \%$ [6]. Rekapitulasi respon mahasiswa terhadap buku petunjuk praktikum fisika pengujian jenis kawat konduktor komersial pada uji coba terbatas I ditampilkan pada Tabel 5 dan uji coba terbatas II ditampilkan pada Tabel 6 .

TABEL 5

REKAPITULASI RESPON MAHASISWA PADA UJI COBA TERBATAS I

\begin{tabular}{clcc}
\hline No & \multicolumn{1}{c}{ Aspek Penilaian } & Persentase & Kriteria \\
\hline 1 & Memacu keingintahuan & $75 \%$ & Baik \\
2 & Penyajian & $78 \%$ & Sangat Baik \\
3 & Tampilan umum & $75 \%$ & Baik \\
4 & Bahasa/keterbacaan & $75 \%$ & Baik \\
5 & Keterlaksanaan praktikum & $74 \%$ & Baik \\
\hline & Rata-Rata Persentase & $76 \%$ & Sangat Baik \\
\hline
\end{tabular}

TABEL 6

REKAPITULASI RESPON MAHASISWA PADA UJI COBA TERBATAS II

\begin{tabular}{clcc}
\hline No & \multicolumn{1}{c}{ Aspek Penilaian } & Persentase & Kriteria \\
\hline 1 & Memacu keingintahuan & $85 \%$ & Sangat Baik \\
2 & Penyajian & $81 \%$ & Sangat Baik \\
3 & Tampilan umum & $80 \%$ & Sangat Baik \\
4 & Bahasa/keterbacaan & $78 \%$ & Sangat Baik \\
5 & Keterlaksanaan praktikum & $77 \%$ & Sangat Baik \\
\hline & Rata-Rata Persentase & $80 \%$ & Sangat Baik \\
\hline
\end{tabular}

Diagram batang hasil respon mahasiswa terhadap buku petunjuk praktikum fisika pengujian jenis kawat konduktor komersial pada uji coba terbatas I dan uji coba terbatas II ditampilkan pada Gambar 2 .

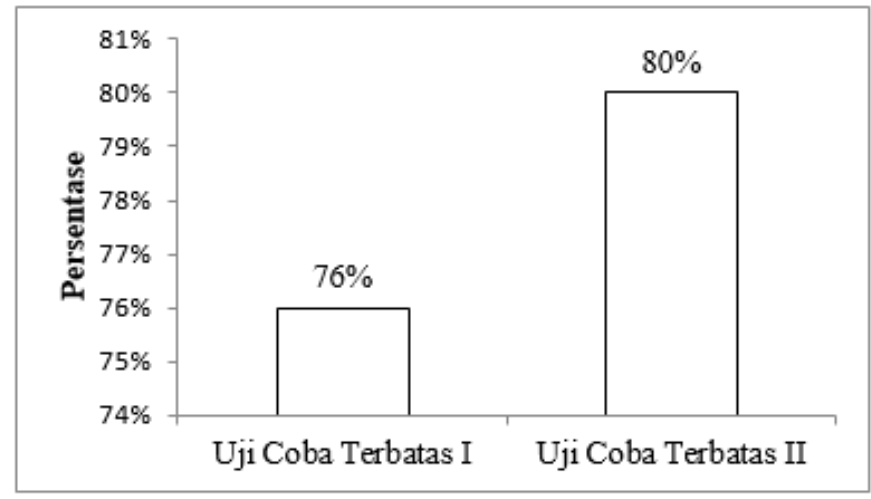

Gambar 2. Diagram Hasil Respon Mahasiswa pada Uji Coba Terbatas I dan Uji Coba Terbatas II

Berdasarkan Gambar 2, hasil respon mahasiswa terhadap buku petunjuk praktikum fisika pengujian jenis kawat konduktor komersial pada uji coba terbatas I diperoleh ratarata persentase sebesar $76 \%$ dengan kategori sangat layak dan mengalami peningkatan pada uji coba terbatas II diperoleh rata-rata persentase sebesar $80 \%$ dengan kategori sangat layak.

\section{KESIMPULAN}

Berdasarkan hasil penelitian diperoleh kesimpulan sebagai berikut: (1) dihasilkan buku petunjuk praktikum fisika pengujian jenis kawat konduktor komersial yang memiliki spesifikasi halaman sampul, halaman kata pengantar, halaman tata tertib praktikum fisika, halaman teori ketidakpastian pengukuran, halaman daftar isi, halaman praktikum, halaman sistematika penulisan laporan praktikum serta halaman daftar pustaka; (2) kelayakan buku petunjuk praktikum fisika berdasarkan hasil penilaian ahli materi diperoleh persentase sebesar 90,00\% dengan kategori sangat layak, berdasarkan hasil penilaian ahli media diperoleh persentase sebesar 95,00\% dengan kategori sangat layak, dan berdasarkan hasil penilaian dosen pengampu mata kuliah listrik magnet diperoleh persentase sebesar $86,76 \%$ dengan kategori sangat layak; (3) buku petunjuk praktikum fisika mendapat respon sangat baik dari mahasiswa dengan persentase mencapai $76 \%$ pada uji coba terbatas I dan pada uji coba terbatas II mendapat respon sangat baik dengan persentase mencapai $80 \%$.

Dengan adanya buku petunjuk praktikum ini diharapkan bisa memberikan alternatif atau pilihan bagi dosen untuk mengajarkan materi hambatan listrik pada mata kuliah listrik magnet. Buku petunjuk praktikum ini juga dapat menambah koleksi buku petunjuk praktikum di laboratorium fisika STKIP Singkawang. Alat dan bahan yang digunakan dalam buku petunjuk praktikum terutama pada jenis kawat yang akan diuji bisa menggunakan jenis kawat lain yang mudah didapatkan di pasaran.

\section{UCAPAN TERIMAKASIH}

Ucapan terima kasih disampaikan kepada Drs. Andi Mursidi, MPA., M.Si. selaku Ketua STKIP Singkawang yang telah memfasilitasi penulis dalam menyelesaikan jurnal ilmiah ini sehingga dapat dipublikasikan dalam Berkala Ilmiah STKIP Singkawang. 


\section{DAFTAR PUSTAKA}

[1] Rosdianto, H. (2017). Penentuan Percepatan Gravitasi Pada Percobaan Gerak Jatuh Bebas Dengan Memanfaatkan Rangkaian Relai. SPEKTRA: Jurnal Fisika dan Aplikasinya. 2 (2), 107-112.

[2] Rosdianto, H. dan Toifur, M. 2017. Implementasi Teori Distribusi Probabilitas Gaussian Pada Kualitas Rangkaian Penyearah Gelombang Penuh. SPEKTRA: Jurnal Fisika dan Aplikasinya. 2 (1), 83-90.

[3] Banu, S. (2011). The Role of Practical Work in Teaching and Learning Physics at Secondary Level in Bangladesh. Tesis. New Zealand: The Collage of Education, University of Canterbury. Tidak dipublikasikan.

[4] Prastowo, A. 2012. Panduan Kreatif Membuat Bahan Ajar Inovatif. Yogyakarta: DIVA Press.

[5] Murdani, E., Sutarno, D. (2011). "Karakterisasi Kawat untuk Sekering Pengaman". Prosiding Simposium Nasional Inovasi Pembelajaran dan Sains 2011 (SNIPS 2011). Prodi Magister Pengajaran Fisika, Fakultas Matematika dan Ilmu Pengetahuan Alam, ITB. 22-23 Juni 2011. Hal. 164.

[6] Sugiyono. 2014. Metode Penelitian Pendidikan Kuantitatif, Kualitatif, dan R \& D. Cetakan kedua puluh. Bandung: Alfabeta.

[7] Crisnandari, Ririn. (2014). "Pengembangan Buku Petunjuk Praktikum Berbasis POE (Predict, Observe, Explain) Materi Listrik Dinamis Kelas X Semester II di MAN Maguwoharjo". Skripsi. Yogyakarta: Program Studi Pendidikan Fisika, Fakultas Sains dan Teknologi, UIN Sunan Kalijaga. Tidak dipublikasikan.

[8] Muhafid, Erfian Arif. (2013). "Pengembangan Modul IPA Terpadu Berpendekatan Keterampilan Proses pada Tema Bunyi di SMP Kelas VIII". Skripsi. Semarang: Program Studi Pendidikan IPA, Fakultas Matematika dan Ilmu Pengetahuan Alam, UNNES. Tidak dipublikasikan. 